further research and more efforts like this one to cross geographical and disciplinary boundaries, an increasingly nuanced understanding of moral and social responses to contagion and disease will emerge.

JOHN GAGNÉ, Concordia University

\title{
Collected Works of Erasmus, Volume 36, Adages IV iii 1 to V ii 51
}

Translated and annotated by John N. Grant and Betty I. Knott, edited by John N. Grant. Collected Works of Erasmus 36

Toronto: University of Toronto Press, 2006. Pp. x, 677.

This is the sixth and last volume presenting the Adages in the Collected Works of Erasmus (CWE); an introductory volume, which will be released as CWE 30, is still in the course of preparation. Like every volume in the whole CWE series, this one is handsomely produced, translated and annotated to a very high standard; like the preceding volume of the Adages, CWE 35 (reviewed in Renaissance and Reformation 29.1 (2005): 125-127), it has the advantage of following the edition of the Latin text of the same adages in the Amsterdam Opera omnia of Erasmus (ASD). As in CWE 31 and 35 , and in contrast with the intermediate volumes of the Adages, the notes are, helpfully, presented at the foot of each page.

Most of the adages in this volume were added by Erasmus in editions of the Adages after the fundamental one of 1508 , and some of them repeat earlier material. For instance, IV ix 99 (in herbis "in the blade") repeats II ii 89 with different examples, as Erasmus admits rather defensively, and IV x 9 (eadem queri "make the same complaint") repeats material from IV viii 88 (concinere "to sing in concert, to agree"). There are few substantial essays among them, an exception being IV v 1 (ne bos quidem pereat "not even an ox would be lost"), which has some interesting autobiographical reflections on scholarship and patronage. There are, indeed, few of the best-known adages of any length: of the 119 adages in William Barker's selection (Toronto, 2001), only four are selected from the range which appears in this volume. Erasmus had perhaps used his best material by the time he came to write the later adages.

Translation and commentary can hardly be faulted. I suspect that at IV iv 54, when after references to dancing bears and performing monkeys, Erasmus complains that a boy or girl may be brought from place to place, gesticulationes ineptas edoctum "taught to act in a silly way," and that vnius puellae calamitas alit ocium quatuor aut quinque robustorum nebulonum, the sturdy wastrels whose leisure time is occupied 
by the calamitas of one girl may be watching her perform a drama rather than, as the commentary here suggests, abusing her sexually. But the hypothesis that the puella is a strolling player would be stronger if calamitas was regularly used to mean "tragedy" in the theatrical sense. The CWE editors are certainly right to see, as Christiane Lauvergnat-Gagnière did not in her ASD commentary, that the passage demands explanation. At one or two other points, their commentary might have been a little fuller: the secret Westphalian law-courts of IV x 6, for instance, are helpfully explained in the ASD volume but not here, and at IV viii 77 the connection between "Mammy's boys" and Greek mammè is baffling until one turns to ASD and finds that the English words translate Greek mammetthreptoi. At V i 75, the observation that "Plato is said to have advised his friends never to make an enemy of a man of poetic bent" is said to be unidentified: AsD locates it in a speech of Socrates in the (pseudo-?) Platonic Minos (320e), and this should have been noted, though Erasmus' form of words certainly suggests that he had the axiom from an indirect tradition.

Sometimes both commentaries leave questions unanswered, and two of these are so puzzling as to be worth mentioning here. First, Erasmus says at IV viii 7 that Galba refused to have his face painted red when he celebrated a triumph. He gives Tacitus as a source, and this appears to be a mistake: but where did he get the story? Second, he says at IV viii 81 that the cuckoo winters in hollow trees, "pulling out its feathers and wrapping itself in them, feeding off a store of apples and pears." The hollow tree is mentioned by other early modern authors, such as Richard Carew, in whose poem "The Spring," the sun "wakes in hollow tree The drowzie Cuckow" (in fact the cuckoo which Erasmus has in mind, cuculus canorus, is a summer migrant to Europe which winters in Africa), but the pulling of feathers and the diet of apples and pears are a puzzle: can they be from an oral tradition?

Questions like these are a reminder of the richness of the learning which shapes the Adages and is required of their translators and editors. The volume under review here maintains the extremely high standards of the CWE series, and completes the work of making a fascinating and immensely important text readily available to all anglophone readers.

JOHN CONSIDINE, University of Alberta 